\title{
Infectious Dose
}

National Cancer Institute

\section{Source}

National Cancer Institute. Infectious Dose. NCI Thesaurus. Code C67448.

A dose at which an infectious org anism can reproduce in the host or the system in which it has been inoculated and to produce measurable effect(s). This effect may not be limited to the display of symptoms, but may also include postconvalescence antibody titers, morphologic changes, development of cellular immunity, and presence of nucleic acid incorporation. 